\title{
STRENGTHENING OF THE STATE EDUCATIONAL POLICY THROUGH THE IMPLEMENTATION OF INTERNATIONAL STANDARDS FOR STUDYING FOREIGN LANGUAGES IN GENERAL EDUCATIONAL INSTITUTIONS OF UKRAINE
}

\author{
Anastasia Zablotska ${ }^{1}$ \\ ${ }^{1}$ Postgraduate Student, Department of Social and Humanitarian Policy, National Academy of Public \\ Administration under the President of Ukraine, Ukraine, Kiev, e-mail: ana.zablotska@ gmail.com
}

Abstract. The article deals with the relationship of quality and modern education in Ukraine with the level of foreign language proficiency in society. The importance of mastering English by students, teachers and scholars, the relevance of learning English under the legal framework of education in Ukraine is highlighted, consistency of the Concept of the "New Ukrainian School" with European trends is substantiated. Researches of international companies that assess the level of English language proficiency in everyday life of Ukrainians and business are presented and analyzed. The national and international approach to assessing students' linguistic competences is outlined and a detailed comparative analysis is provided. The instruments of approximation of standards of preparation and assessment of speech competences to the international ones are described, as well as the conceptual approximation of the school to the needs of the international market. A description of a pilot project (experiment) in Irpin (Kyiv Oblast), which was implemented to identify and improve English language skills among students and teachers, is provided, and the results of this experiment are highlighted. The way of synchronization of curricula in general and vocational training institutions with the programs of the international standard of competence in foreign language is presented, the importance of this educational task is substantiated.

Keywords: educational policy, language competence, New Ukrainian School, educational institutions, reform, education rating, External independent evaluation, CEFR, certification, international standards.

JEL Classification: I20, I21, I26, I28

Formulas: 0; fig.: 0; tabl.: 1; bibl.: 18

Introduction. The issue of quality and up-to-date education in Ukraine is of paramount importance and is one of the key priorities for the authorities, and the top politicians of various cadences have always stated this fact. Today, the educational system is undergoing transformational processes as part of decentralization. A number of laws have been adopted including the Law of Ukraine "On Education", Decree of the Cabinet of Ministers of Ukraine On Approval of the Concept of Implementation of the State Policy in General Secondary Education Reform "The New Ukrainian School" for the Period till 2029, Regulations on the educational district and others. The legal framework in the field of educational decentralization creates the preconditions for the autonomy and free development of educational institutions at different levels in Ukraine. For example, it is the introduction of a new State standard for basic education, the digitization of education, and only the very beginning of the process of establishing the National Qualifications System which is the link between the labor market and education, as well as the introduction of new mechanisms for teacher professional development, i.e. a voluntary certification and the "money for teacher" mechanism.

Literature Review. Various aspects of professional training of future specialists in their scientific works have been studied by domestic and foreign scientists and 
practitioners. Thus, the issues of formation and development of higher education in Ukraine in general have been studied in the scientific works of P. Atamanchuk, V. Bezlyudna, L. Berezivska, O. Bugayov, S. Velychko, S. Honcharenko, N. Gupan, E. Korshak, O. Lyashenko , G. Meshko, N. Slyusarenko, O. Sukhomlynska, N. Terentyeva, K. Trybulkevych, O. Sergeev, M. Shut and others. O. Varnikova, O. Zabolotska, A. Dolapchi, G. Karlovska, G. Kitaygorodska, Y. Kotova, L. Lichman, $\mathrm{K}$. Matiychuk, N. researched the issues of teaching foreign languages in the education system of Ukraine and in preparatory departments in higher education institutions. Mykytenko, E. Myronenko, L. Morska, S. Nikolaeva, N. Primina, V. Strekozyn, L. Stupina, O. Frolova and others.

Aims. The objective of our study is to systematize the main approaches of the methodology of the editorial office of U.S. News and World Report [2] to the rating of the educational institutions and analyzing the changes herein introduced to create the 2020 rating and the reasons for editing; identification of the major motivational reason for creating such ratings according to the indicated editorial office.

Methods. The author used the methods of static and logical comparison, systematization and generalization, which made it possible to achieve the goal of the study.

Results. At present, about 10 million of Ukrainian citizens are studing at high school, in the system of vocational and higher education. And this is not just a significant figure against the population of our country. This is the greatest potential directly proportional to Ukraine's prospect of becoming an economically developed and prosperous European country capable of competing with world economies.

The education is directly related to Ukraine's success in the world market, especially now when the President and the Government are actively engaged in attracting foreign investment at the Davos Forum and all investment activities. The projects "Ukraine.Now", the opening of the "UkraineInvest" office under the Government, the launch of the "Magnets" program and other initiatives show the country's political readiness for opening global relations. Entering the international market means an international level of education and the ability to communicate internationally thanks to English skills. Therefore, the ability to use international languages is one of the main global competences.

Knowledge of English in today's world is a kind of window into the world. By mastering this language of international communication, everyone will be able to achieve the goals set in our globalized world. Therefore, the importance and learning of English is an extremely relevant topic today. In general, the political, economic, scientific, sporting life of the whole world is administered and broadcast in English. All international summits and meetings of heads of governments, signing of important treaties, debates are all conducted in English.

The international trade, operation of the banking system, activities of the transport system are carried out in English. International conferences, learning the world's practice and exchange of information are conducted only using English. The Olympic Games and all sorts of competitions between countries have chosen English as their official language. Movies made in the US have confidently come into our 
lives, and any pop singer finds it prestigious to sing at least one song in English. The importance of English in the modern world is so great that its knowledge is not a luxury. It is taught everywhere: at schools, universities, courses. Any educated person is simply obliged to know English, because it is the key to further self-education and self-improvement.

The Concept of the New Ukrainian School is focused precisely on the acquisition of not only knowledge but mainly of competencies by school students. The competence is a dynamic combination of knowledge, abilities, skills, ways of thinking, attitudes, values and other personal qualities that determines a person's ability to successfully socialize, pursue professional and / or further educational activities. That is, a core of knowledge is formed, which will be enriched by an ability to use this knowledge, as well as the values and skills that will be needed for school-leavers of the Ukrainian school in their professional and private life [4].

The list of competences that high school students will acquire is already established by the Law On Education. The list was created on the basis of the "Recommendation of the European Parliament and of the Council of Europe on the Formation of Key Competences for Lifelong Learning" (dated December 18, 2006) [4]. It is worth noting that the second priority in terms of competences is the ability to communicate using the native tongue (in case it is different from the official language) and foreign languages.

The private educational company EducationFirst (EF) has published the results of an annual survey of the level of English in 80 countries, according to which the level of English in our country is rated as "low". Only 18\% of Ukrainians speak English at intermediate level. The initial data for it are the results of the EFSET (EF StandardEnglishTest) test, which can be taken for free on the company's website [15]. Last year, about 1 million people took advantage of this opportunity.

It is important to note that the percentage of Ukrainian scholars out of the stated above $18 \%$ of English speakers is minimum. Usually, scientists use translated books, articles and other materials, whose translation takes considerable time and information gradually loses its relevance to science, and in general, only its small part is translated into Ukrainian. That is, teachers and scholars, due to their lack of knowledge of foreign languages at a sufficient level, remain significantly isolated from progressive world discoveries, research and, in general, ideas including pedagogical ones.

The fact that the overall level of English in Ukraine is critically low is confirmed by another study from EF Education First, which looks at the use of language in a business environment. If you look at the overall ranking of countries by level of English, it may seem that it is not so bad: Ukraine is somewhere in the middle (49th out of 88) among all countries in which English is not native. That is, only within one year (from 2018-2019) Ukraine has lost 6 points in the rating and has fallen from the category of "medium leve" to "low level" [15]. Also it is frustrating that Russia, Uruguay, Belarus, Guatemala ranked higher as compared to Ukraine

The private educational company Education First (EF) published the results of an annual survey of the English language proficiency in 80 countries. 
Looking at the statistics for Europe, our country ranks 28th in the list of 33 (Table 1). The rating compilers, however, point out to the correlation of annual per capita income to the level of linguistic knowledge, and this partly explains the low rating of Ukraine. We can note a positive factor in this regard, ie the number of people having the English language skills is sufficient in Kyiv rate it closer to the top of the list of the capital cities.

Table 1

EF English Proficiency Index (Europe)

\begin{tabular}{|l|l|l|l|l|l|l|l|}
\hline \multicolumn{2}{|c|}{ Very high level } & \multicolumn{2}{c|}{ High level } & \multicolumn{2}{c|}{ Moderate level } & \multicolumn{2}{c|}{ Low level } \\
\hline Netherlands & $\mathbf{7 0 . 2 7}$ & Croatia & $\mathbf{6 3 . 0 7}$ & France & $\mathbf{5 7 . 2 5}$ & Belarus & $\mathbf{5 2 . 3 9}$ \\
\hline Sweden & $\mathbf{6 8 . 7 4}$ & Hungary & $\mathbf{6 1 . 8 6}$ & Latvia & $\mathbf{5 6 . 8 5}$ & Russia & $\mathbf{5 2 . 1 4}$ \\
\hline Norway & $\mathbf{6 7 . 9 3}$ & Romania & $\mathbf{6 1 . 3 6}$ & Spain & $\mathbf{5 5 . 4 6}$ & Ukraine & $\mathbf{5 2 . 1 3}$ \\
\hline Denmark & $\mathbf{6 7 . 8 7}$ & Serbia & $\mathbf{6 1 . 3 0}$ & Italy & $\mathbf{5 5 . 3 1}$ & Albania & $\mathbf{5 1 . 9 9}$ \\
\hline Finland & $\mathbf{6 5 . 3 4}$ & Switzerland & $\mathbf{6 0 . 2 3}$ & & & Georgia & $\mathbf{5 0 . 6 2}$ \\
\hline Austria & $\mathbf{6 4 . 1 1}$ & Lithuania & $\mathbf{6 0 . 1 1}$ & & & Turkey & $\mathbf{4 6 . 8 1}$ \\
\hline Luxembourg & $\mathbf{6 4 . 0 3}$ & Greece & $\mathbf{5 9 . 8 7}$ & & & Azerbaijan & $\mathbf{4 6 . 1 3}$ \\
\hline Germany & $\mathbf{6 3 . 7 7}$ & Czech Republic & $\mathbf{5 9 . 3 0}$ & & & & \\
\hline Poland & $\mathbf{6 3 . 7 6}$ & Bulgaria & $\mathbf{5 8 . 9 7}$ & & & & \\
\hline Portugal & $\mathbf{6 3 . 1 4}$ & Slovakia & $\mathbf{5 8 . 8 2}$ & & & & \\
\hline Belgium & $\mathbf{6 3 . 0 9}$ & Estonia & $\mathbf{5 8 . 2 9}$ & & & & \\
\hline
\end{tabular}

Sourse [16]

However, the state is taking important steps in shaping public educational policy to remedy this situation. The latest positive developments in educational Ukraine may be illustrated with the fact that the English language proficiency has become one of the prerequisites for enrollment into most Ukrainian universities. The Ministry of Education of Ukraine has selected English as one of the three compulsory subjects for the basic test for admission to higher educational establishments, i.e. the External independent evaluation. The latter is a tool that has a clear purpose which is to rank the students who want to enter higher educational institutions. Thus, the preparation of students who are about to leave the school (grades 10-11) for the External independent evaluation is an important element not only for completing high school education, but also for making a significant contribution to their future.

As the Ukrainian Center for Education Quality Assessment, with the support of the Ministry of Education and Science of Ukraine, has introduced the differentiation of the English language test under of the External independent evaluation into the profile and academic levels, which, in turn, meets the international standards of English proficiency at the B1 and B2 levels according to the The Common European Framework of Reference for Languages (CEFR) [13]. It should be noted that not two separate works of different complexity are referred to under levels B1 and B2, but one test work with tasks of different levels of difficulty.

The need to prepare a high school leaver to complete the External independent evaluation as minimum as at the international B2 level (i.e. higher than the average) is obvious. High school students who study a foreign language at the standard level have to take only 43 out of 59 tasks to receive a grade under the State Final Certification. All 59 tasks must be completed in order to receive the result of the 
External independent evaluation. The students studying at the speciliased level must complete all the tasks both for the State Final Certification and for admission. Thus, in order for a future student to be able to enter a university where one of the main requirements is passing the English Language Test as part of the External independent evaluation (such universities are prevailing nowadays), the necessity to prepare a high school leaver to take the External independent evaluation at the international B2 level is obvious.

At the B2 language level a language learner can:

- understand basic ideas of complex texts on abstract and specific topics, including technical topics related to his / her specialization;

- interact with some degree of fluency and immediacy, making regular interaction with native speakers possible with no strain on either side;

- make clear, detailed messages on a wide range of issues and can present his / her views on the main problem, show the advantages and disadvantages of different options [13].

Ukrainian schools require the maximum approximation of standards of the preparation and assessment of language competences to the international ones, and therefore, generally, the conceptual approximation of schools to the needs of the international market. In other words, there will be a very slow and unofficial integration of the educational Ukrainian standard in CEFR (short for Common European Framework of Reference). It is a system designed specifically to assess the level of proficiency in a particular European language by matching skills to specific criteria.

The recommendations of Carlos Cesar Jimenez from the National Autonomous University of Mexico, Ludwig Wittgenstein in the 1950s and the sociolinguist Del Hymes have laid the theoretical basis of this system [14]. This approach views the language as a social agent that develops general and specific communication skills when meeting daily goals.

General and specific communication skills are developing by producing or receiving texts of different contexts under different conditions and different level of stress or tension. These contexts correspond to different parts of social life, called domains. There are four main domains according to the international practice including initial, professional, public and personal. The user can develop different levels of language proficiency in each of these domains and, in order to describe them, the Recommendations provide a set of common reference levels.

The state vector of bringing the state standard of education in Ukraine to international standards is reflected in a number of normative legal acts, in particular: in the Law of Ukraine On Education dated 01.09.2017 No. 2145-VIII; Decree of the CMU On Approval of the Concept of Implementation of the State Policy in General Secondary Education Reform "The New Ukrainian School" for the Period till 2029 dated 14.12.2016; Order of the Ministry of Education and Science of Ukraine No 1222 dated 21.08.2013 On approval of approximate requirements of the evaluation of educational achievements of high school students in basic disciplines in the general secondary education system, the Law of Ukraine On Vocational Education dated 
10.02.1998 No 103/98-VR, etc. And the formation of the National Qualifications System should serve as a guide between labor market and education.

Taking into account the instruments provided by the legal framework, a pilot project-experiment of assessing and training of high school students and teachers by international standards was launched in Irpen (Kyiv region) in 2019. All high school students participating in the program passed the External independent evaluation in English at the highest level in Ukraine in 2019, which proves the effectiveness of the program. EILTS and TOEFL standards were used to evaluate and teach both children and high school students, and the Teaching Knowledge Test (TKT) was used to train teachers. The project was implemented in collaboration with municipal high schools and a private English language center. The project budget amounted to UAH 500,000 .

Several municipal steps were taken under this municipal program, namely: 1) English language proficiency among high school students of all schools was assessed, 2) English language proficiency among all English language teachers in the city was assessed, 3) teacher training courses were organized, 4) additional English training sessions were organized for high school students of different schools, 5) results of the External independent evaluation were obtained. $45 \%$ of the teachers scored sufficient number of points that corresponds to the international B2 level or higher, which is not enough to train a high school student to the same level. Only $20 \%$ of brave teachers (those who came for voluntary testing) showed a level that corresponds to a candidate for admission to a foreign university (only bachelor) or an average candidate for a position at an international company. The results of the high school students were consistent with those of their teachers, but slightly lower. This means that most high school leavers are unable to use English at a level sufficient for admission to foreign universities, nor for mid-level positions in international companies.

In 2019, a pilot on voluntary teacher certification was launched as part of the New Ukrainian School with the aim of identifying and encouraging teachers with a high level of professional skills who use proficient teaching methods and new educational technologies and promote their dissemination. This tool can be used in the process of motivating English teachers to increase their teaching level to the international one. Based on the example of the pilot project in Irpin, a system of incentivation was offered to teachers. It boiled down to the following: provided that the teacher successfully passed the English language tests at B2 level, he / she could receive double pay for a year. However, as the experiment showed, the teachers' fears of failing to take independent tests far outweighed their desire to receive a very substantial salary supplement. This situation indicates the unwillingness of teachers to ranking according to international criteria among their colleagues and, accordingly, to open incentive systems.

Discussion. To move this problem in line with the positive trend, it is necessary to conduct a pilot of synchronization of curricula in secondary and vocational schools with programs of the international standard of competence in a foreign language. To achieve this goal, it is important to focus on the following tasks: 
- development of methodical recommendations on synchronization of school curricula with CEFR;

- development of teacher training program (advanced training) according to CEFR standards;

- improvement of the system of incentives for teachers who will participate in the project (for example, successful certification of a teacher based on the results of the project guarantees a $20-50 \%$ salary supplement);

- development of a regulation on public-private partnership for the study of foreign languages on the basis of the Ukrainian school with the involvement of private foreign languages learning centers and international companies;

- creation of the domestic prototype of CEFR programs in demo and full versions on the basis of the National Qualifications System, as well as introduction of the system of domestic Certification;

- general testing of students of the 10th and 11th grades of secondary schools, as well as English teachers in accordance with the international competence of CEFR on English language proficiency in listening, writing, reading and speaking practice;

- training during the school year for high school students and teachers according to the CEFR integrated methodology of international competence, the use of this methodology in the Centers for Advanced Training;

- certification and testing of learning outcomes, comparison of the results with the intial ones, improvement of the program for use at the national level.

The main short-term results of this approach include the following:

- increasing the level of English language proficiency among high school students and English teachers in all components including listening, reading, writing, speaking;

- overcoming the language barrier and developing skills of comfortable communication with native speakers;

- developing synchronized curricula in general secondary education according to international standards;

- activating the National Qualifications System;

- preparing for obtaining international certificates, which automatically increases the chances of employment for adults, exemption from the State Final Certification tests for high school students.

The long-term results include the following:

- strengthening the state educational policy through the introduction of international standards for learning foreign languages;

- increasing Ukraine's capacity to get integrated into the world community and attract investment projects;

- increasing the ability of the Ukrainian school to compete with European educational institutions, the entry of the Ukrainian school into the world market;

- increasing the potential of Ukrainian high school students to attract or be involved in global projects; 
- launching a system of public-private partnership on the basis of schools (increasing the financial capacity of the education system);

- creating an independent assessment system for having a command of a language which can be equivalent to the international standard of CEFR.

Today in Ukraine the preconditions for the rapid development of the educational sphere have been created. Although the decentralization process bears some risks to the financial capacity of major institutions and regular schools, it provides considerable freedom (autonomy) and a new level of responsibility for the educational product. The example of Irpen clearly shows that amalgamated territorial communities or municipalities can independently develop their own programs, determine funding, attract an expert community and hold responsibility for the efficient use of funds.

Decentralization also opens up opportunities for public-private partnerships, which is extremely important in the context of learning English in educational institutions. Private companies transfer a high level of competence in using or teaching English, and schools should take advantage of this, even on an individual basis. The role of the school principal is acquiring a new quality and is being formed as a subject of educational quality in the community. However, to this end the school principal (manager) must be highly educated and he / she should demonstrate it, be competent, respond to global trends, have no language barriers, be able to seek new sources of funding and cooperate with different types of enterprises (public, private, corporations).

Conclusions. Every year the world rankings indicate a systematic decline in terms of the English language proficiency among Ukrainians, including those in the business environment. This signals a gradual decline in the ability of Ukrainian institutions to get integrated into European and international structures. Given the constant lack of funding for education, this situation indicates significant risks in providing quality modern education in educational institutions. A number of steps and requirements have been introduced under the state programs to motivate the increase of English language proficiency as a language of international communication. The said programs include the following: prioritization of learning foreign languages in the list of competencies in the concept of the "New Ukrainian School", priority of the External independent evaluation in English in schools with the requirement of compliance with the international B2 level, and a mandatory certificate of English B2 for a PhD degree seekers.

The powers and resources of amalgamated territorial communities due to the reform of decentralization and the current legislation in the field of local selfgovernment can be considered as a mechanism to accelerate the entry of educational institutions into the market of educational entities. Communities that have already used the provided tools and have shown a successful outcome may serve as an example of it. All options are effective provided effective management of the city or school including a system of incentives for teachers, attracting additional resources, public-private partnership, school autonomy. And best of all is a fruitful cooperation of government, educational managers, business and the responsible community. For 
Ukrainian high school students to have a good command of English is the key to gaining subjectivity by Ukraine in the world.

\section{References:}

1. The Verkhovna Rada of Ukraine (1996), The Law of Ukraine "Constitution of Ukraine", retrieved from : https://zakon.rada.gov.ua/laws/show/254\%D0\%BA/96-\%D0\%B2\%D1\%80.

2. The Verkhovna Rada of Ukraine (2017), The Law of Ukraine "On education", retrieved from : https://zakon.rada.gov.ua/laws/show/2145-19.

3. The Verkhovna Rada of Ukraine (1997), The Law of Ukraine "On local self-government in Ukraine", retrieved from : https://zakon.rada.gov.ua/laws/show/280/97-\%D0\%B2\%D1\%80.

4. The official website of Ministry of Education and Science of Ukraine (2020), "New Ukrainian School", retrieved from : https://mon.gov.ua/ua/tag/nova-ukrainska-shkola.

5. The official website of Cabinet of Ministers of Ukraine "Government Courier" (2017), "Actual problems of school education in Ukraine", retrieved from : https://ukurier.gov.ua/uk/articles/aktualni-problemishkilnoyi-osviti-v-ukrayini/.

6. The official website of Decentralization (2018), "Note to OTG: School Education Network Capability Index", retrieved from : https://decentralization.gov.ua/news/8889.

7. Sharleia, R. Kavunets, A. V. Bezpalko, O. M. Moskalu, M. and Lanova, A. I. (2018), Yevropeiski stratehii dlia mistsevykh hromad Ukrainy ta Moldovy: dosvid krain Vyshehradskoi chetvirky [European strategies for the local communities of Ukraine and Moldova: experience of the Visegrad countries], TOV «Nilan-LTD», Vinnytsia, Ukraine, 76 p.

8. The official website of the Decentralization (2016), "Guidelines for the creation of a unified territorial community education management system", retrieved from https://old.decentralization.gov.ua/pics/attachments/2016-02-22-1.pdf.

9. The official website of Decentralization (2018), "The mechanism of distribution of additional subsidies for the maintenance of educational and health institutions in the oblasts: expert opinion", retrieved from : https://decentralization.gov.ua/news/8790.

10.Seitosmanov, A. Fasolia, O. and Markhlievski, V. (2017), Nova shkola u novykh hromadakh: posibnyk $z$ efektyvnoho upravlinnia osvitoiu $v$ obiednanykh terytorialnykh hromadakh [New School in New Communities: A Guide to Effective Governance in United Territorial Communities], Kyiv, 128 p.

11.Markhlievski, V. and Protsak, O. (2018), Stratehiia rozvytku osvity v hromadi [A strategy for the development of community education], Kyiv, Ukraine, 56 p.

12.Kavunets, A. Lanova, A. Humenna, O. Chernii, O. and Sharleia, R. (2018), Upravlinnia systemoiu osvity terytorialnykh hromad: dosvid krain Vyshehradskoi chetvirky dlia Ukrainy [Management of the system of education of territorial communities: experience of the Visegrad countries for Ukraine], TOV «Tvory», Vinnytsia, Ukraine, $120 \mathrm{p}$.

13.The official website of Wikipedia (2019), "Pan-European recommendations for language education", retrieved from : https://uk.wikipedia.org/wiki/Загальноєвропейські_рекомендації_3_мовної_освіти.

14.Jimenez, C. C. (2011), "El Marco Europeo Común de Referencia para las Lenguas y la comprensión teórica del conocimiento del lenguaje: exploración de una normatividad flexible para emprender acciones educativas (essay). Universidad Nacional Autónoma de México", retrieved from : https://www.academia.edu/1440597/El_Marco_Europeo_Com\%C3\%BAn_de_Referencia_para_las_Lenguas _y_la_comprensi\%C3\%B3n_te\%C3\%B3rica_del_conocimiento_del_lenguaje_exploraci\%C3\%B3n_de_una _normatividad_flexible_.

15.EF EPI "EF English Proficiency Index" (2018), retrieved from https://www.ef.com/_/ /media/centralefcom/epi/downloads/full-reports/v9/ef-epi-2018-english.pdf.

16.EF EPI "EF English Proficiency Index" (2019), retrieved from https://www.ef.com/_/ /media/centralefcom/epi/downloads/full-reports/v9/ef-epi-2019-english.pdf.

17.The official website of European Commission (2018), "Key competences and basic skills", retrieved from : https://ec.europa.eu/education/policy/school/competences_en.

18.The official website of OECD (2018), "Adult education level", retrieved from : http://data.oecd.org/eduatt/adult-education-level.htm. 